\title{
Transition to the Circular Economy in the Fashion Industry: The Case of the Inditex Family Business
}

\author{
Karina Nicolle Esbeih ${ }^{1, *}$, Valentín Molina-Moreno ${ }^{1} \mathbb{D}$, Pedro Núñez-Cacho ${ }^{2} \mathbb{D}$ and Bruna Silva-Santos ${ }^{2} \mathbb{D}$ \\ 1 Department of Management, University of Granada, 18071 Granada, Spain; vmolina2@ugr.es \\ 2 Polytechnic School of Linares, University of Jaén, 23071 Jaén, Spain; pnunez@ujaen.es (P.N.-C.); \\ bss00009@red.ujaen.es (B.S.-S.) \\ * Correspondence: kesbeih@correo.ugr.es
}

Citation: Esbeih, K.N.;

Molina-Moreno, V.; Núñez-Cacho, P.; Silva-Santos, B. Transition to the Circular Economy in the Fashion Industry: The Case of the Inditex Family Business. Sustainability 2021, 13, 10202. https://doi.org/10.3390/ su131810202

Academic Editor: Paolo Rosa

Received: 6 July 2021

Accepted: 23 August 2021

Published: 13 September 2021

Publisher's Note: MDPI stays neutral with regard to jurisdictional claims in published maps and institutional affiliations.

Copyright: (c) 2021 by the authors. Licensee MDPI, Basel, Switzerland. This article is an open access article distributed under the terms and conditions of the Creative Commons Attribution (CC BY) license (https:/ / creativecommons.org/licenses/by/ $4.0 /)$.

\begin{abstract}
Society is increasingly concerned about aspects of work related to sustainability. This leads organizations to reflect on the economic, environmental, and social problems that affect both current and future generations. When companies identify an environmental problem, they try to respond to it through changes in their environmental policies, aiming at the transition towards sustainability. In this context, the circular economy appears as a regenerative industrial system that replaces the concept of "end of life" with that of "restoration". It is oriented to the use of renewable energies, eliminating the use of toxic chemicals, which are harmful to reuse. The theory of socio-emotional wealth describes the behavior patterns of family businesses in response to the environmental changes that occur and the reasons derived from the family character that make them move towards the circular economy model. This article studies the case of the Spanish textile manufacturing and distribution multinational Inditex, analyzing the information collected in its environmental balances in the period 2013-2018. The analysis allows us to observe the speed of Inditex's transition to the circular economy. For this, transition speed indicators were formed in each of the dimensions of the circular economy model. The results of the study indicate areas in which the company is moving faster and those in which more effort is needed. Finally, a collection of good practices related to the CE used by Inditex is provided.
\end{abstract}

Keywords: transition; speed of transition; Inditex; environmental management systems; sustainable clothing; indicators; smart textile sustainability; stakeholders' sustainability; SEW

\section{Introduction}

Up to the year 2016, the economic model was based on a linear process that proceeded from raw materials to the elimination of waste from products that consumers were not going to use: basically take-make-consume-eliminate [1]. In recent years, industries have tried to ensure sustainability and efficiency in production conditions in their supply chains. [2]. When reviewing sustainable development, it is necessary to pay attention to social, economic, and environmental problems, seeking a balanced interaction between these aspects and trying to minimize the negative externalities that affect current and future generations [3]. Governments of different countries [4] are adopting economic actions to push European companies and consumers to make the transition towards a stronger and greater circular economy (CE), in which resources are used in a more sustainable way. This system aims to eliminate waste through the design of materials, products, and systems and, through this, obtain business models [5]. The European Union (EU), seeking a more competitive and sustainable economy, is developing different legal provisions to reduce the use of resources and the generation of waste, promoting sustainable consumption and production. Sustainable consumption and production consist of promoting the efficient use of resources and energy, the construction of infrastructures that do not harm the environment, the improvement of access to basic services and the creation of ecological jobs, well remunerated and with good working conditions [6]. 
The European Commission and many governments already fully recognize that the CE provides new jobs; a substantial increase in GDP saves valuable resources and reduces dependence on imports. The creation of a circular economy center at the Member State level is probably the only way to generate examples that can convince national stakeholders [1]. The concept of CE has its roots in environmental, ecological, and industrial economic areas, where the proposed system is intended to replace the current linear economic model, enabling products and services to be reused, recovered and recycled, maximizing their useful life and thus shortening the production chain. The pressure in terms of environmental issues is high, especially for those with a significant environmental impact $[7,8]$. Environmental problems, such as water, air and soil pollution; loss of biodiversity; resource depletion; and excessive use of land, are increasingly putting life support systems on earth at risk [9].

The objective of this study was to determine the situation of family businesses in relation to environmental sustainability in order to identify the impact of the transition from the linear economy to the circular economy in these companies, specifically analyzing the case of the company Inditex. We studied how it is driving the transition to CE in each of the dimensions proposed. For this purpose, we used socio-emotional wealth theory (SEW) as a theoretical foundation.

Specifically, the research questions are:

- RQ1: What factors inherent to the family help the implementation of the CE model?

- RQ2: How is the transition from the linear economy to the $\mathrm{CE}$ being put into practice at Inditex?

- RQ3: In what dimensions related to CE is Inditex driving the transition towards this model with more force?

By answering these research questions, we aim to contribute to progress in devising conservative models of sustainable family businesses by investigating the behavior of a family and firm in the face of the CE. We also wanted to introduce into the new model the decision-makers in family businesses, all persons who are affected by the operations of the company and who are known as stakeholders [10].

With this research, we wanted to identify how the transition from the linear economy to the circular economy is being put into practice at Inditex. Likewise, we aimed to investigate the treatment that the company offers for recycling, negative externalities, its waste, and its materials, thus determining the importance of the transition to the CE.

\section{Theoretical Framework of the Research}

A wide variety of companies continue to operate in an unsustainable traditional linear economy of "take, make, use and waste". On the other hand, the circular economy (CE) is an economic system that represents a paradigm shift in the way in which human society interacts with nature, one which aims to avoid the depletion of resources, take care of energy and materials, and facilitate sustainable development [11]. Countries such as Germany, France, UK, Japan, and China have begun to develop policies that they approve through regulations to facilitate the implementation of strategies for the transition towards the circular economy in their societies [11].

Being considered a new paradigm for the consumption and production systems, the circular economy aims to preserve and repair natural capital and, at the same time, improve the performance of resources and reduce the risks arising from the process [12]. Therefore, it consists of a positive development cycle that favors the care of the environment and nature as well as the economic profitability and well-being of society, seeking to ensure that biological and technological resources last throughout the value chain of the products that are manufactured and consumed by the population and having, as a rule, the optimization of resources [12].

The expectations that society has are not met due to problems such as high unemployment, poor working conditions, social vulnerability, poverty, intra- and intergenerational equity, and the high number of inequalities [9]. 
In this sense, at present, it is possible to observe a gaze trend as a vision of an economy with a new system where benefits are provided to the population, companies, and above all-natural benefits. Taking this panorama behind the CE presents structuring elements in that sense, exposing a new way of designing, manufacturing, and using things within the limits of the planet without damaging the environment [13]. In this sense, it is evident that the potential of the circular economy is taken by the entities and actors that work in favor of the environment as the solution to this growing problem.

In contrast, the current production system is based mainly on a linear process of resource consumption. Under the "take-make-waste" model, goods are produced from raw materials, then sold, used by customers, and finally disposed of as waste, which causes the generation of tons of garbage, over and above the depletion of natural resources [14].

$\mathrm{CE}$ is a proposed sustainable development system, which aims to improve the use of energy and the efficiency of materials $[15,16]$. This system replaces the "end of useful life" in production and consumption processes, by minimizing, reusing, recycling, and restoring materials. Its purpose is the protection of the environment, reducing negative externalities and promoting sustainable economic development [17].

According to Stahel, "In old times, life extension and reuse were strategies applied in situations of poverty or scarcity [18]. At present, they are signs of management of resources and an intelligent administration value propositions that a business proposes to its clients" [19].

The notions of CE are built around recycling and reducing the consumption of materials. Progress towards CE will work only if state authorities conceptualize it and transmit that vision to industry and citizens [20]. CE is a regenerative or restorative economic industry by intention and design [21]. This is a growing issue, particularly in the European Union, which encourages responsible development and the cyclical use of resources that can help with sustainable development. According to Céspedes, the CE differs from the linear economy in its position regarding the use of resources (one restorative and the other exhausting), in the environmental impact, while one tries to reduce it, the other degrades it and in innovation and economic growth sustainable in CE versus the unsustainable model of the line [21].

We conceive the $\mathrm{CE}$ as an economic system that aims to redesign the resources that are going to be used, which will be made available for the growth in benefits of society. Unlike the linear economy, it involves the correct consumption of resources and the design of the waste system to improve economic activity. Changing from the linear economy to CE entails economic, natural, and social capital. The principles are to keep products and materials in use, design the waste and pollution system, and regenerate natural systems [22] (pp. 169-181). This whole process of change from a traditional linear system is what we understand by the transition to CE.

Therefore, by applying CE principles, the company evolves towards a more sustainable model. Sustainability could be defined as the "balanced incorporation of social inclusion, economic results and the resilience of the environment, for the benefit of current and future generations" [23].

\subsection{Principles of the Circular Economy}

Since the industrial revolution, the progress of technology has continued very rapidly. The results of the innovations mean that many now have access to products from all over the world. Our way of doing things is coming to a halt [13]. Currently, every second, a textile truck is burning. We use the earth's resources to manufacture products, we make them useful and when we no longer need them, we throw them away [13]. Take-do-waste. We call this linear economics. Nowadays, thanks to technology, we have the knowledge and tools to help us create an economy suitable for the 21st century [13].

The following three principles according to the Ellen MacArthur Foundation are the foundations of a new system: designing waste and pollution, keeping products and material in use, and regenerating natural systems. This will provide benefits of $48 \%$ 
reduction in carbon dioxide emissions by 2030, a EUR 3000 increase in disposable income per year for households in the European Union, CNY 70 billion savings for companies and households in China. In 2040, there will be a $47 \%$ reduction in traffic congestion in Chinese cities, with 700 million dollars per year of savings in material costs in the fast consumer goods industry. This is performed by the CE [13].

$\mathrm{CE}$ is based on three fundamental principles. First, preserving and improving the environment are fundamental. If there is a need for more resources, models of reuse cycles must be designed and technologies that use renewable resources must be adapted. Second, optimizing the performance of resources, using materials to the maximum, designing to remanufacture, reconditioning and recycling and thus keep material in circulation. Third, eliminating negative externalities from design through effective systems. In this way, minimizing damage to human use such as food, mobility, housing, education, and health, using renewable energy by nature [13].

Because companies have many unsustainable practices [24], CE aims to solve these environmental cost problems. Each production system must deal with its production inefficiencies to minimize environmental damage. These damages are called "negative externalities". They originate in decisions that are related to consumption, production, the exchange of inputs, and factors of production and investment. By reducing negative externalities, family businesses will minimize their environmental impact and thus maintain their long-term objective [24].

This model increases the need for decision-makers in the family business to seek the reduction in these externalities. The transformation of the linear model towards CE will help to minimize the negative effects [25].

\subsection{Socioemotional Wealth Theory (SEW)}

SEW is one of the ideas in the literature that is related with great importance to the family business [26] whose subject has a short trajectory; however, concerning the general approach, it means a hopeful direction of the futures investigations in all the analysis of evaluation of the company, performance, social responsibility, adventure, diversification, and the concept given with the family company in focus [27].

Family members acquire SEW from different sources, for example, the surname being added with their companies, the emotional affinity to the company [28] and the joy of the members who work in the company [29].

The elements of SEW are family control and influence $(\mathrm{F})$; the identification of the family members with the signature (I); long-term relationships with different clients (B); emotional ties between members (E) and passing on the legacy (R) [30]. For the members of future generations of companies [31], preserving values, family unity and harmony is truly relevant for the generation of social and economic value. Families are a social group with a long history including memories that last forever where emotional exchanges affect both their members and family businesses [32].

According to Debicki et al., SEW is made up of three fundamental dimensions: Firstly, the importance of how society perceives the family as the owner of a business [33]. Issues such as concern for corporate honor are considered, which could lead to the adoption of more sustainable practices seeing it from an environmental point of view [34] because the company pursues a positive organizational reputation [35]. Secondly, family persistence, which means how important it is to make decisions based on the sustainability of the family business and the desire to preserve family ownership and management. Thirdly, family progress shows the importance of the aspiration to maintain family harmony and unity through disinterested behavior, a characteristic that distinguishes family businesses $[36,37]$.

\subsection{Circular Economy and Fashion}

The fashion industry has a huge impact on the environment, with increasing results around the world [38]. Fashion consumers and stakeholders should assess the current status quo, in compliance with the principles of CE and sustainability [38]. By encouraging 
the development of products that are based on sustainability (such as cleaner technologies, green and recyclable products), CE can be a guide for the fashion industry [38].

To become circular, the fashion industry must reinvent itself in how to design, what materials to use, how to dye, cut and sew, ship, sell, own, use and dispose of fashion [39]. New technology, business models, and materials can make this possible [39]. By transforming into a circular model, the fashion industry will be able to produce fashion for a growing world population while operating within planetary limits and ensuring a viable long-term business. A shift towards circular fashion will also bring new benefits to the industry such as reducing material costs, accessing new markets, improving customer relationships, and reducing the risks of resource depletion [40]. CE is an alternative to the linear economy where the resources are kept in use for a longer time, taking the maximum value of them while they are in use, and recovering and regenerating materials and products at the end of their life. CE is powered by renewable energy such as solar, wind, hydro energy [41].

\subsection{Establishing the Model for Analysis}

\subsubsection{Introduction}

With this article, we want to show the importance and emphasize that it is necessary to change the linear model, presenting as a solution the Circular Economy for companies in the textile industry, through which cycles are created where resources move from circular shape within the entire production and consumption system, thus reducing pollution to the environment, preserving human life.

Because, in the 21st century, the concern for environmental problems and impacts [12], caused by the pollution that companies are generating due to being subjected to linear methods, has become more visible, we analyze all the aspects in which the textile sector would favor to reduce this impact, using the proposed circular economy model.

We rely on Dubin's theoretical model, based on the functionalist prototype, to raise the model through deduction. By reviewing the literature and operating with selected variables, we fabricate a theory by extension that increases from previous models [41]. Following Dubin's methodology, a literature review was made in journals and scientific databases to understand the phenomena and the progress of concepts and in this way identify previous models and important aspects of the investigation.

Next is to find the largest number of studies that have been carried out with the subject we are investigating. To obtain these studies, we use search engines and chains. Those used in this research are: Science Direct, Web of Science, ResearchGate, Scopus, and Google Scholar. However, for the search string, keywords that are related to the variables of the research topic were selected.

They used the operators (AND, OR and AND NOT) to generate complex searches. After an arduous review process, 74 references on the subject were selected, which are included in indexed journals, and which were helpful as a basis for the bibliographic analysis.

\subsubsection{Development of an Analysis of Relationships between Community, Family, and Company}

According to Dubin, the objective of the construction analysis is to establish the fundamental dimensions of the domain [42]. The three basic constructions of our theory are community, family, and company. We choose these dimensions where the authors argue that the sustainability of family businesses is caused by the balance between business and family $[43,44]$. Long-lived family businesses benefit from the constant commitment to the local community because these enhance their socio-emotional wealth. The community is damaged by the negative externalities produced by business, the increased consumption of resources and the lack of these that the manufacturing industry and society face [21]. In the next step of the study, Danes et al. design the evolution of the previous models, adding the community as one more part [45]. These authors argue that sustainability in the family business environment originates in the community environment, where the company relates to the community through the exchange of resources. 
The family is the owner of the company and wants to protect the socio-emotional wealth by acting in a socially responsible way, since this behavior will cause social recognition, benefiting the economic and non-economic achievement from the implementation of practices that have more respect with the environment.

Community is defined as a dynamic method that constantly originates and recreates. It offers institutions, resources, cultural values, beliefs, attitudes, and practices that can be used to achieve objectives [46-48].

A company is an economic, productive, and financial entity. Both the community and the family and the company interact with each other. Both the family and the company respond regularly to disorders [49].

Figure 1 is a relationship cloud that shows the topics that the family, community, and company are related to. This cloud was made to show everything that the family, community, and company are involved in and thus demonstrate the importance that each of these has. They have implications in different areas, such as health, education, sustainability, government, economy, family characteristics, poverty, knowledge, among others, that relate to these three states.

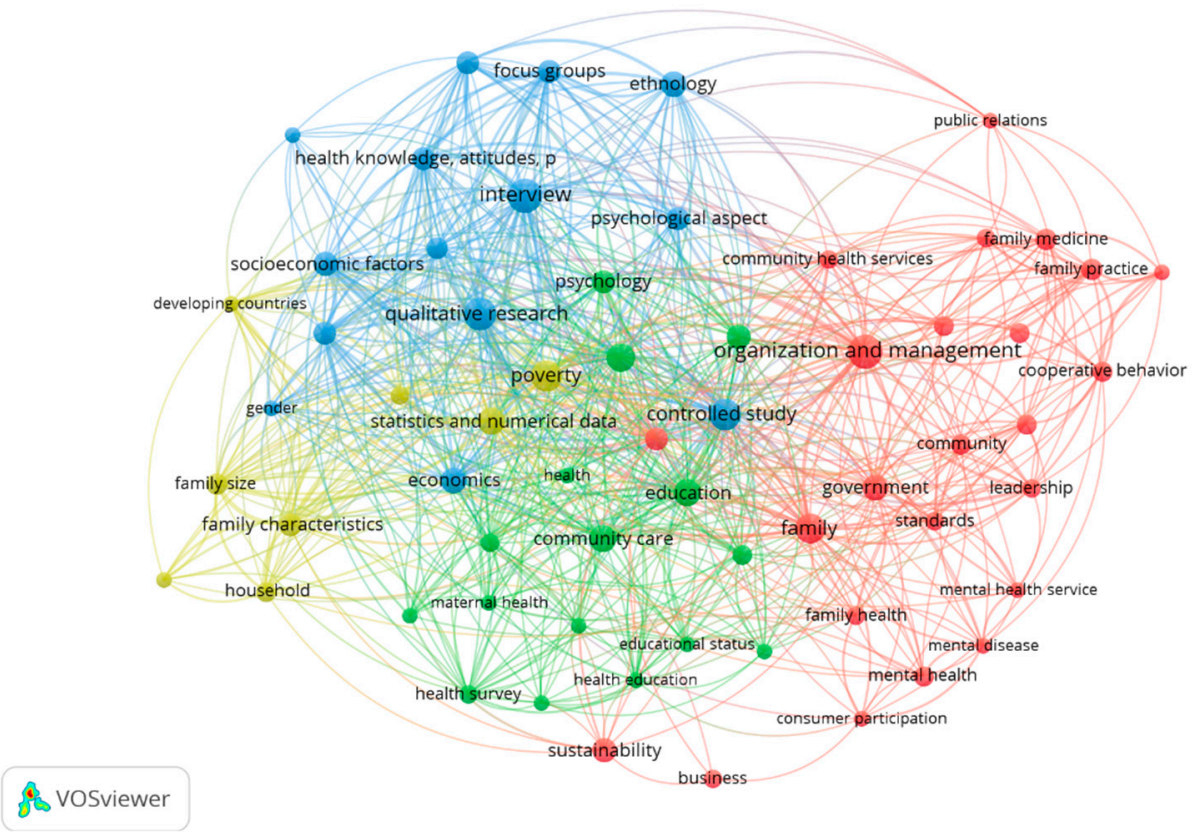

Figure 1. Relationship: Community-Business-Families. [50] Sources: VOS Viewer-The authors.

They have implications in different areas, such as health as an effect in the reduction in emissions and waste that could affect water, forest and soil and the welfare of human beings; in education in learning and knowledge of the 3 R's (recycle, reuse, reduce) and environmental awareness; strengthening sustainability by the triangulation of social, environmental and economic aspects; and in government by the establishment of proposals, legislation and regulations in favor of environmental development and CE, and as an economic result in the generation of employment and profitability of business operations, helping to reduce poverty and knowledge management of good practices, which relate to these three states.

\section{Inditex}

Inditex, Industrias de Diseño Textil, S.A., is the world's leading fashion retailer. Formed by eight commercial brands-Zara, Massimo Dutti, Pull and Bear, Bershka, Stradivarius, Oysho, Zara Home and Uterquë-it has more than 4500 stores in 73 countries and its headquarters are in Arteixo, La Coruña. These eight brands account for more than 7400 physical stores, approximately 171,000 employees and a presence in around 140 markets [50]. 
In 1963, D. Amancio Ortega Gaona founded a company dedicated to the manufacture of clothing that grew progressively to have several manufacturing centers, which distribute their product to different countries. In 2008, Inditex launched its latest brand, Uterqüe, dedicated to the world of accessories. By the end of that year, Inditex was already present in 72 countries [51].

\section{Transition to CE in Family Businesses: The Inditex Case}

\subsection{Proposed Theoretical Model}

New construction is made in the theoretical model, a statement about the model that is working is strengthened [43,52]. The propositions are based on the built-in predictive and explanatory capacity added to the theoretical framework caused during the advancement of the theory [53]. The indicators must be transformed into experimental data and then into the hypothesis. These hypotheses are tested through research, associating theory with reality. Dubin noted that the propositions do not involve experimental exactitude, on the contrary, they are exact if they logically originate from the theoretical framework [43].

According to a widely accepted and articulated definition [54], stakeholders (interested parties) are any person who affects or is affected by the operations of a company [55]. A company must work through its relationships with stakeholders to enhance the creation of joint value, which is important to the success of the organization [56]. Internal stakeholders are those who have direct participation in the decision-making processes. The external stakeholders are those that can affect or can be affected by the activities of the organization [55].

Stakeholders can be classified as primary or secondary [57]. The former being essential for the survival of the organization through its commitment, and the latter are those that are influenced or affected by an organization. In addition, it can be classified as normative, directly involved in the transactions and derivatives of the organization, affecting the organization, or affected by its actions [58].

The literature increasingly emphasizes the importance of applying the principles of sustainable development in which stakeholders play an important role [55]. Figure 2 presents the proposed model.

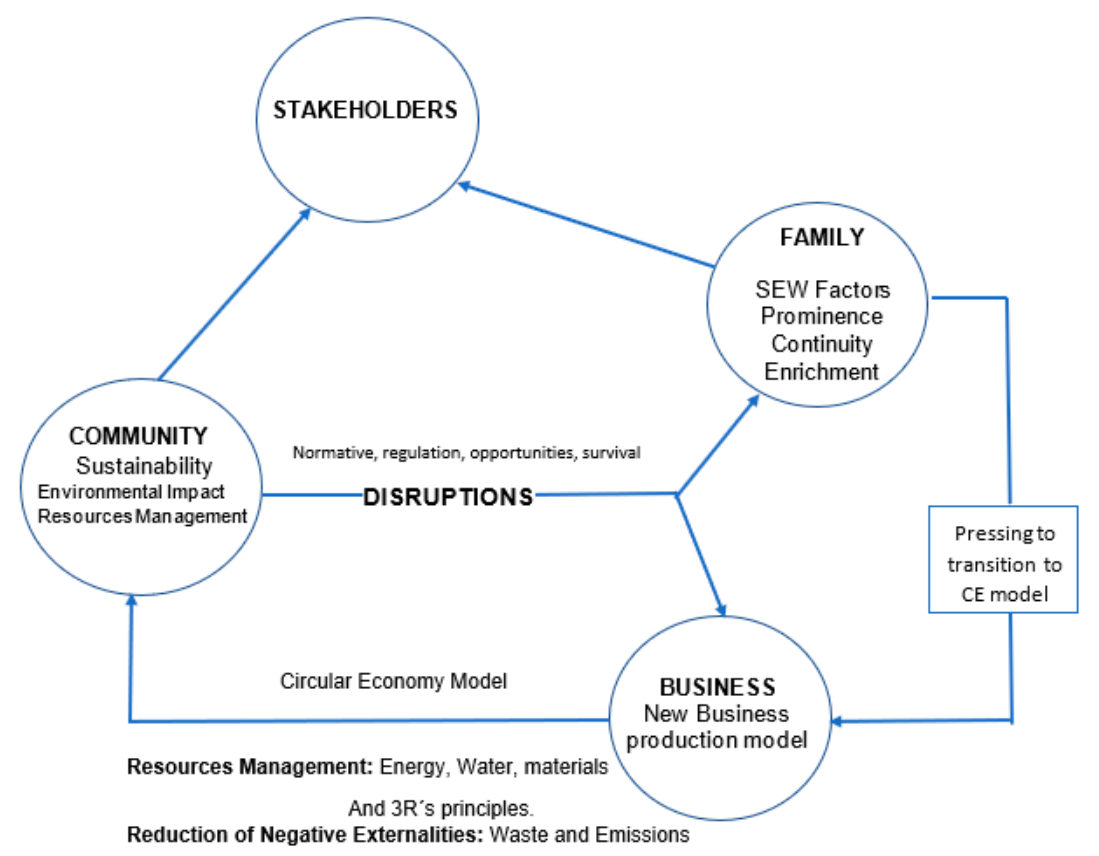

Figure 2. Transition to the circular economy of the family business in the fashion sector. Source: [3].

\subsection{Methodology}

To measure the application of the proposed CE model, analysis and integration of the methodologies of Campopiano and De Massis [59] were made using grounded theory 
with a body of empirical evidence gathered through content analysis (attachment No. 2), this "grounded theory" referring to a theory developed inductively from a set of data and oriented towards action, a "method of analysis that allows examining the interactive nature of events" [60].

Grounded theory analysis informs and contextualizes several differences in the type of content of corporate social responsibility reports of family businesses, we gather important information about the principles that have been developed in the theoretical part of the company [59].

Regarding the methodology of analysis, we used the approach that allowed us to recognize the factors that harm the speed with which companies transition to CE.

The methodology used for content analysis is a method to encrypt the written text in different categories or groups concerning chosen criteria. For this, we use the "third-party approach", in which the analysis is carried out by someone other than the provider and recipient of the report [61]. This analysis is a long-used means of reaching unavailable information since it tends to avoid the common remember biases of interviews [62].

We also collect important information from secondary sources such as websites, news, and social media $[63,64]$. With all the information collected from the corporate website, we were able to understand the business models that the company follows and study the environment of the sector and the company. Then, the content analysis was combined with the information obtained from the database during the period 2017-2018. We analyzed the Inditex reports for the years 2013 to 2018, due to the longitudinal record and behavior of the variables of interest. Although information from 2020 to 2021 is identified, it is incomplete due to key records and information, so we extracted the indicators shown in the article [64]. To calculate the speed of transition we used the next indicators:

$$
S_{i}=\frac{V_{i n}-V_{i 0}}{V_{i 0}}
$$

where:

$S_{i}=$ Speed of transition of indicator

$V_{\text {in }}=$ Score of the indicator $i$ on the year $n$

$V_{i 0}=$ Score of the indicator $i$ on the year 0

\subsection{Analysis of the Energy Transition towards CE at Inditex in the 2013-2018 Period}

The global energy consumption of the different Inditex facilities comes mainly from the consumption of electricity from the grid and, to a lesser extent, from the consumption of fossil fuels (natural gas and diesel) and renewable energies. Table 1 shows the indicators on energy consumption derived from our factories, headquarters, chain headquarters, as well as from our logistics centers and all our stores located in the different countries of the world.

All its facilities are built under sustainable architecture criteria and include the most innovative technology for efficient management and energy saving in their equipment. In the fight against climate change, Inditex has continued to invest in improving the efficiency of its logistics facilities and headquarters, consolidating its commitment to energy from renewable sources. It should be noted that they continue to work so that all their stores meet the requirements of the Eco-efficient Store Manual, which is already a reality for $71 \%$ of their stores.

At Inditex, they prioritize both the consumption of renewable energies and the integration of photovoltaic and solar thermal panels in their energy supply scheme. Additionally, facilities for the use of geothermal energy and wind generation are given priority. If they are added to the trigeneration plants, cogeneration. The commitment to efficiency and its commitment to clean energy is evident due to the investment in infrastructures and technologies. In 2025, it is expected that $80 \%$ of the energy consumed by the company will come from renewable energies. The company also has developed an Efficiency plan in logistics centers, betting on more efficient technologies such as LED lighting or the latest 
generation batteries. Moreover, they manage to reduce their energy requirements while improving their efficiency. On the other hand, the company seeks to ensure that the stores meet the requirements of the eco-efficient store standard, including new openings and renovations. The company has achieved the intensity of energy use in relation to its sales. It has also made a very rapid transition towards the use of renewable energies, going from $3.28 \%$ in 2013 to $43 \%$ in 2018 (see Table 1). The speed of transition-related to diesel consumption in relation to sales is also especially significant, with a reduction in the period of $78.48 \%$.

Table 1. Inditex group energy and speed of transition by indicators.

\begin{tabular}{cccccccc}
\hline Indicator & $\mathbf{2 . 0 1 8}$ & $\mathbf{2 . 0 1 7}$ & $\mathbf{2 . 0 1 6}$ & $\mathbf{2 . 0 1 5}$ & $\mathbf{2 . 0 1 4}$ & $\mathbf{2 . 0 1 3}$ & Speed (Si) \\
\hline Global Energy MJ & $7,086,858.00$ & $6,845,665.00$ & $6,674,201.00$ & $6,542,018.00$ & $6,357,960.00$ & $6,095,030.00$ \\
\hline Global Energy/Sales & 271.06 & 270.20 & 286.31 & 313.02 & 350.94 & 364.45 & $-25.62 \%$ \\
\hline Consumption MWh & $1,969,127.00$ & $1,901,574.00$ & $1,853,945.00$ & $1,817,227.00$ & $1,765,782.00$ & $1,679,752.00$ \\
\hline Consumption/Sales & 75.32 & 75.05 & 79.53 & 86.95 & 97.47 & 100.44 & $-25.01 \%$ \\
\hline Consumption Natural Gas & $103,724.00$ & $97,703.00$ & $101,875.00$ & $112,051.00$ & $104,262.00$ & $109,996.00$ \\
\hline Gas Consumption/Sales & 3.97 & 3.86 & 4.37 & 5.36 & 5.75 & 6.58 \\
\hline Gasoil Consumption MWh & 329.00 & 299.00 & 357.00 & 1291.00 & 869.00 & 978.00 \\
\hline Gasoil Consumption/Sales & 0.0126 & 0.0118 & 0.0153 & 0.0618 & 0.0480 & 0.0585 & $-\mathbf{7 9}$ \\
\hline Renewable Energy & $837,626.00$ & $734,567.00$ & $529,678.00$ & $177,679.00$ & $63,654.00$ & $54,898.00$ \\
\hline Renewable/Sales & 32.04 & 28.99 & 22.72 & 8.50 & 3.51 & 3.28 \\
\hline Ratio & 0.43 & 0.39 & 0.29 & 0.10 & 0.04 & 0.03
\end{tabular}

\subsection{Analysis of the Water Transition at Inditex in the 2013-2018 Period}

The water supply in all centers (headquarters, Inditex factories, logistics centers and own stores) comes from public and authorized supply networks that are used for both consumption and processes. The greatest consumption of water is carried out in domestic uses, mainly cleaning and sanitary, guaranteeing its discharge to municipal sanitation networks. In the industrial field, the main activities with water requirements are steam generation and closed-cycle industrial refrigeration, where recirculation systems are used. As there are no production processes in which water is consumed, and the cooling systems are in a closed cycle, it can be estimated that the water discharged is equal to the water consumed. The wastewater discharges from all the facilities are made to the sanitation networks. The water consumption data come from direct measurements and receipts from suppliers (public supply networks) at their headquarters, Inditex factories, logistics centers and own stores. Thanks to the efficiency and water-saving measures carried out in its centers, the downward trend in relative water consumption per garment and relating to sales (EUR) continues to improve, respectively, by $13 \%$ and $8 \%$. The increase observed in absolute terms is due to the growth of its commercial area. In Table 2 shown above, we can see the water consumption for the years 2013 through 2018 for Inditex group and the relationship with the sales. The company has reduced the intensity of water use in relation to its sales by $118.35 \%$ 
Table 2. Inditex group water and speed of transition by indicators.

\begin{tabular}{cccccccc}
\hline Water & $\mathbf{2 . 0 1 8}$ & $\mathbf{2 . 0 1 7}$ & $\mathbf{2 . 0 1 6}$ & $\mathbf{2 . 0 1 5}$ & $\mathbf{2 . 0 1 4}$ & $\mathbf{2 . 0 1 3}$ & Speed (Si) \\
\hline Water Consumption & 54.898 & 63.654 & 177.679 & 529.678 & 734.567 & 837.626 \\
\hline Water Consumption/Sales & 20,998 & 25,124 & 76,221 & 253,434 & 405,457 & 500,853 & $-118.35 \%$ \\
\hline \multicolumn{3}{c}{ Source: Own Authors. }
\end{tabular}

\subsection{Analysis of the Transition to CE at Inditex: Reduction in Waste Generated in the} 2013-2018 Period

In 2012, Inditex adhered to the Zero Discharge of Unwanted Substances Commitment to minimize the environmental impact of its products and improve the health of its garments and the safety of the workers in its supply chain. Since then, they have oriented their control and manufacturing improvement strategies to achieve the elimination of unwanted chemical substances. This commitment has materialized in three programs whose objectives are to work towards: the identification of risks throughout the manufacturing chain; the substitution of substances included in the List of Restricted Substances in Manufacture; and transparency in these processes.

Likewise, they are aware of the need to reduce the generation of waste in their value chain, which is why they have implemented projects such as Closing the Loop, an initiative for the collection of used clothing, or the Green to Pack, which contributes to the efficiency of shipments.

All the waste generated by Inditex is collected and managed by legally authorized managers who will send the waste for recycling (in the case of paper and cardboard, plastics, metal, textile waste, etc.) and other appropriate treatments that allow its recovery. In 2018, they managed to recycle and valorize more than $90 \%$ of their hazardous waste, preventing it from going to a landfill and reducing the need to obtain new raw materials. Thanks to the tasks of separation at source and subsequent shipment to legally authorized managers, they promote recycling or other appropriate treatments that allow the recovery of hazardous waste. The company has a commitment to zero discharge of unwanted chemicals (ZDHC Commitment, Zero Discharge of Hazardous Chemicals) with its supply chain. In addition, it maintains a goal of Zero Waste to Landfill in 2020 in the generation of waste at its corporate headquarters, logistics centers, stores, and its factories.

The packaging materials that they put on the market associated with their products (cardboard and plastic bags, labels, protective elements), are effectively managed by authorized managers. Inditex adheres to the Integrated Management Systems for Containers and Packaging available in the countries in which it operates, which means that each Inditex chain pays a non-profit management entity the cost of collection and management of waste generated by stores. This managing body, established with the recognition of the authorities of each country, guarantees that the waste generated by the stores is collected, managed, and recycled properly. In Table 3, we show the annual waste generation of the different materials that are used by Inditex in different years. Table 3 shows that the company managed to reduce textile and metal waste in the 2013-2018 period. However, Cardboard, Plastic and Wood were not able to reduce the generation of this waste.

Regarding the recovery of commercialized products, it is not feasible to evaluate the volume generated and the management carried out worldwide, since there is no specific collection and management system for textile materials at a global level. Through the Closing the Loop Program, we contribute by creating a channel that allows the reuse and recycling of said products. Table 4 includes the annual generation of hazardous waste of the different materials used, the annual relationship with sales and its percentage of speed. The company has transitioned towards the circular economy in this regard, highlighting the reduction in electronic waste and batteries. Plastic containers and cadmium batteries do not perform well and little was improved in these respects. 
Table 3. Annual Generation of Inditex Waste.

\begin{tabular}{|c|c|c|c|c|c|c|c|}
\hline Annual Waste Generation & 2.018 & 2.017 & 2.016 & 2.015 & 2.014 & 2.013 & Speed (Si) \\
\hline Textile & 521,229 & 523,258 & 575,812 & $1,831,142$ & 619,656 & 625,074 & \\
\hline Textile waste/sales & 20 & 21 & 25 & 88 & 34 & 37 & $-46.66 \%$ \\
\hline Cardboard and paper & $14,193.929$ & $13,111,084$ & $12,243,127$ & $11,065,644$ & $9,233,987$ & $8,133,323$ & \\
\hline Cardboard/sales & 543 & 517 & 525 & 529 & 510 & 486 & $11.63 \%$ \\
\hline Plastic & 712,435 & 689,985 & 776,277 & 744,934 & 415,158 & 352,775 & \\
\hline Plastic/sales & 27 & 27 & 33 & 36 & 23 & 21 & $29.18 \%$ \\
\hline Wood & $3,609,294$ & $3,726,574$ & $2,898,468$ & $2,070,567$ & $2,037,907$ & $1,718,895$ & \\
\hline Wood/sales & 138 & 147 & 124 & 99 & 112 & 103 & $34.31 \%$ \\
\hline Metal & 166,363 & 300.05 & 254,799 & 720,345 & 0 & 0 & \\
\hline Metal/sales & 6 & 12 & 11 & 34 & 0 & 0 & $-81.54 \%$ \\
\hline Other & $2,574,720$ & $2,578,800$ & $2,401,428$ & $1,966,431$ & $1,980,065$ & $1,554,604$ & \\
\hline Other/sales & 98 & 102 & 103 & 94 & 109 & 93 & $5.94 \%$ \\
\hline
\end{tabular}

Source: Own Authors.

Table 4. Inditex's Annual Generation of Hazardous Waste.

\begin{tabular}{|c|c|c|c|c|c|c|c|}
\hline $\begin{array}{c}\text { Annual Generation of } \\
\text { Hazardous Waste }\end{array}$ & 2.018 & 2.017 & 2.016 & 2.015 & 2.014 & 2.013 & Speed (Si) \\
\hline Batteries & 2929 & 5507 & 9532 & 7945 & 6580 & 9193 & \\
\hline Batteries/sales & 0.112 & 0.217 & 0.409 & 0.380 & 0.363 & 0.550 & $-79.62 \%$ \\
\hline Electronic Waste & 6673 & 6901 & 10,094 & 9776 & 10,149 & 25,091 & \\
\hline Electronics/sales & 0.255 & 0.272 & 0.433 & 0,468 & 0.560 & 1.500 & $-82.99 \%$ \\
\hline Fluorescents & 2827 & 3183 & 5.387 & 26,000 & 6207 & 3446 & \\
\hline Fluorescents/sales & 0.108 & 0.126 & 0.231 & 1.244 & 0.343 & 0.206 & $-47.52 \%$ \\
\hline Oil filters & 671 & 500 & 761 & 659 & & & \\
\hline Filters/sales & 0.026 & 0.020 & 0.033 & 0.032 & 0.000 & 0.000 & $-18.61 \%$ \\
\hline Contaminated metal containers & 530 & 865 & 2284 & 1064 & & & \\
\hline Containers/sales & 0.020 & 0.034 & 0.098 & 0.051 & 0.000 & 0.000 & $-60.18 \%$ \\
\hline Used mineral oil & 4432 & 8302 & 15,080 & 8242 & & & \\
\hline Oil/sales & 0.170 & 0.328 & 0.647 & 0.394 & 0.000 & 0.000 & $-57.01 \%$ \\
\hline Contaminated absorbents & 3259 & 4262 & 2786 & 4969 & 5818 & 6873 & \\
\hline Absorbents/sales & 0.125 & 0.168 & 0.120 & 0.238 & 0.321 & 0.411 & $-69.67 \%$ \\
\hline Batteries Nickel Cadmium & 784 & 751 & 562 & 594 & & & \\
\hline Batteries/sales & 0.030 & 0.030 & 0.024 & 0.028 & 0.000 & 0.000 & $5.51 \%$ \\
\hline Contaminated plastic containers & 1648 & 1578 & 1366 & 1521 & 1740 & 1061 & \\
\hline Plastic container/sales & 0.063 & 0.062 & 0.059 & 0.073 & 0.096 & 0.063 & $-0.64 \%$ \\
\hline
\end{tabular}

Source: Own Authors.

\subsection{Analysis of the Transition to CE at Inditex: Emission Reduction in the 2013-2018 Period}

We observed the set of actions to promote energy efficiency in Section 3.1. Table 5 shows the $\mathrm{CO}_{2}$ Emission reduction rate in the different scopes and the relationship with the sales. Together with the materialization of their commitment to renewable energies through the purchase of 520 million KWh of electricity from certified renewable sources, it has allowed them to reduce GHG emissions in absolute terms. Relatively, per garment a reduction stands out between 2013 and 2018 of $40.21 \%$ in the Scope 1/sales indicator, which includes all direct emissions from the activities of an organization or under its control. Including fuel combustion at the site, such as gas boilers, fleet vehicles, and air conditioning leaks. On the other hand, the reduction in the Scope 2/sales indicator in the analyzed period was 50.42, indirect emissions of electricity purchased and used by the organization are included here. Emissions are created during energy production and are ultimately used by the organization. Finally, the emissions collected by the Scope 3/sales indicator increased by $26.2 \%$. This reflects the other indirect emissions from activities of the organization, which are produced from sources that they do not own or control. 
Table 5. Inditex $\mathrm{CO}_{2}$ Emissions Reduction Rate 2013-2018 period.

\begin{tabular}{|c|c|c|c|c|c|c|c|}
\hline Emissions & 2.018 & 2.017 & 2.016 & 2.015 & 2.014 & 2.013 & Speed (Si) \\
\hline Scope1 & 21,055 & 19,083 & 20,689 & 22,996 & 21,347 & 22,525 & \\
\hline Scope1/sales & 0.81 & 0.78 & 0.89 & 1.10 & 1.18 & 1.35 & $-40.21 \%$ \\
\hline Scope2 & 486,957 & 470,629 & 540,312 & 622,879 & 666,188 & 627,982 & \\
\hline Scope2/sales & 18.63 & 18.58 & 23.18 & 29.80 & 36.77 & 37.55 & $-50.40 \%$ \\
\hline Scope3TT & 926,764 & 921,405 & 825,294 & 672,307 & 596,316 & 462,120 & \\
\hline Scope3TT/sales & 35.45 & 36.37 & 35.40 & 32.17 & 32.91 & 27.3 & $28.28 \%$ \\
\hline Scope3TCL & 676,642 & 639,039 & 549,913 & 428,258 & n.d. ${ }^{1}$ & n.d. ${ }^{1}$ & \\
\hline Scope3TCL/sales & 25.88 & 25.22 & 23.59 & 20.49 & & & $26.30 \%$ \\
\hline Scope3TF & 129,710 & 121,171 & 103,923 & 94,262 & 113,094 & 108,035 & \\
\hline Scope3TF/sales & 4.96 & 4.78 & 4.46 & 4.51 & 6.24 & 6.46 & $-23.20 \%$ \\
\hline Scope3 total & $1,733,116$ & $1,681,615$ & $1,479,130$ & $1,194,827$ & 709,410 & 570,155 & \\
\hline Scope3 total/sales & 66.29 & 66.37 & 63.45 & 57.17 & 39.16 & 34.09 & $94.44 \%$ \\
\hline Scope total & $2,241,128$ & $2,172,074$ & $2,040,131$ & $1,840,702$ & $1,396,945$ & $1,220,662$ & \\
\hline Scope total/sales & 85.72 & 85.73 & 87.52 & 88.07 & 77.11 & 72.99 & $17.44 \%$ \\
\hline
\end{tabular}

${ }^{1}$ n.d.: Not Defined. Source: Own Authors.

\subsection{Analysis of the Transition to CE at Inditex: Materials in the 2013-2018 Period}

Regarding materials, Inditex pursues the manufacture of products based on more sustainable fibers, also using the best available production techniques with less environmental impact so that the impact in this phase is as low as possible. In addition, it also seeks to reduce emissions derived from the value chain and promote a low-carbon economy.

Table 6 shows the summary of all the good practices in sustainability at Inditex, including stores, programs, materials, and policies that make Inditex a more sustainable company every day.

Table 6. Summary of good practices in sustainability at Inditex.

\begin{tabular}{|c|c|c|c|}
\hline Eco-Efficient Store & Green to Pack & The List by Inditex & $\begin{array}{c}\text { Húmedos Clear to Wear and } \\
\text { Safe to Wear }\end{array}$ \\
\hline $\begin{array}{l}\text { Inditex stores incorporate the } \\
\text { most innovative technology in } \\
\text { energy management and } \\
\text { saving, allowing the reduction } \\
\text { in carbon dioxide }\left(\mathrm{CO}_{2}\right) \\
\text { emissions. The sustainability } \\
\text { and energy efficiency } \\
\text { measures of these stores save } \\
\text { on average } 20 \% \text { in electricity } \\
\text { and up to } 40 \% \text { in water } \\
\text { consumption compared to a } \\
\text { conventional store. }\end{array}$ & $\begin{array}{l}\text { It is a program that seeks to } \\
\text { reduce the consumption of } \\
\text { raw materials in its packaging } \\
\text { and improve the density of } \\
\text { shipments, increasing the } \\
\text { number of products } \\
\text { transported in each shipment. } \\
\text { In addition, the use of more } \\
\text { sustainable materials in their } \\
\text { packaging was promoted, } \\
\text { favoring reuse, and their } \\
\text { subsequent separation and } \\
\text { recycling. }\end{array}$ & $\begin{array}{l}\text { It is a pioneering program } \\
\text { worldwide for the } \\
\text { improvement of chemical } \\
\text { products used in the } \\
\text { manufacture of textile and } \\
\text { leather garments. Through } \\
\text { manufacturing audits and } \\
\text { product analysis and their } \\
\text { subsequent classification, } \\
\text { improvements in the use of } \\
\text { these chemical substances are } \\
\text { established. }\end{array}$ & $\begin{array}{l}\text { These are the Inditex Group's } \\
\text { product health and safety } \\
\text { standards, mandatory for all } \\
\text { its garments and } \\
\text { incorporating the strictest and } \\
\text { most up-to-date legislation on } \\
\text { the matter. }\end{array}$ \\
\hline Sustainable raw materials & New recycled fibers & Ready to Manufacture & Closing the Loop \\
\hline $\begin{array}{l}\text { In the elaboration of their } \\
\text { garments, they bet on the } \\
\text { incorporation of fabrics that } \\
\text { allow them to reduce their } \\
\text { environmental impact and } \\
\text { protect biodiversity, such as } \\
\text { organic cotton, which does } \\
\text { not need fertilizers or } \\
\text { chemical pesticides, or } \\
\text { TEN-CEL }{ }^{\circledR} \text { Lyocell, a fiber } \\
\text { from wood from sustainably } \\
\text { managed forests. }\end{array}$ & $\begin{array}{l}\text { Inditex incorporates recycled } \\
\text { cotton, wool and polyester } \\
\text { into its garments, fibers whose } \\
\text { manufacture consumes less } \\
\text { water, energy, and natural } \\
\text { resources than the production } \\
\text { of new fibers. It has started } \\
\text { new lines of research on } \\
\text { recycling textile fibers and } \\
\text { developed Refibra TM } 1 \\
\text { Lyocell, made from cotton } \\
\text { waste generated by Inditex } \\
\text { and wood from sustainably } \\
\text { managed forests. }\end{array}$ & $\begin{array}{l}\text { Ready to Manufacture (RTM) } \\
\text { is a code of good } \\
\text { manufacturing practices for } \\
\text { textile and leather articles for } \\
\text { wet process facilities (dry } \\
\text { cleaners, laundries, tanneries } \\
\text { and stamping), which } \\
\text { guarantees compliance with } \\
\text { the demanding Inditex health } \\
\text { standard. }\end{array}$ & $\begin{array}{l}\text { Project for the reuse and } \\
\text { recycling of garments in } \\
\text { collaboration with third sector } \\
\text { entities, recycling companies } \\
\text { and fabric manufacturers. In } \\
\text { the stores, they enable specific } \\
\text { containers to facilitate the } \\
\text { donation of their customers. } \\
\text { Likewise, they have placed } \\
\text { containers in all their offices } \\
\text { and logistics centers in Spain, } \\
\text { to promote this initiative } \\
\text { among their employees. }\end{array}$ \\
\hline
\end{tabular}


Table 6. Cont.

\begin{tabular}{|c|c|c|c|}
\hline Eco-Efficient Store & Green to Pack & The List by Inditex & $\begin{array}{c}\text { Húmedos Clear to Wear and } \\
\text { Safe to Wear }\end{array}$ \\
\hline Join Life y Wear the Change & Forest policy & CanopyStyle & Green to Wear \\
\hline $\begin{array}{l}\text { With the aim that its } \\
\text { customers can quickly identify } \\
\text { those products that stand out } \\
\text { for their respect for the } \\
\text { environment, some Inditex } \\
\text { brands have launched specific } \\
\text { collections of more sustainable } \\
\text { products. Zara identifies these } \\
\text { products with the Join Life } \\
\text { label, while at Oysho the use } \\
\text { of raw materials such as } \\
\text { organic cotton, TENCEL }{ }^{\circledR 2} \\
\text { Lyocell or recycled fibers are } \\
\text { recognized with the } \\
\text { distinctive Wear the Change. }\end{array}$ & $\begin{array}{l}\text { Inditex seeks to ensure that all } \\
\text { its activities are carried out } \\
\text { sustainably and protecting } \\
\text { primary and endangered } \\
\text { forests from extinction. In } \\
\text { addition, they work to ensure } \\
\text { that the forest-based } \\
\text { man-made fibers they use in } \\
\text { their products come from } \\
\text { sustainably managed forests. } \\
\text { Forest products with a high } \\
\text { content of recycled material } \\
\text { and post-consumer waste are } \\
\text { prioritized. }\end{array}$ & $\begin{array}{l}\text { Under the Canopy Style } \\
\text { initiative promoted by the } \\
\text { Canopy Planet organization, } \\
\text { Inditex and other leading } \\
\text { brands in the textile sector } \\
\text { continue to promote artificial } \\
\text { cellulosic fibers. Together with } \\
\text { nine other large vegetable } \\
\text { fiber suppliers, Inditex } \\
\text { committed to guaranteeing } \\
\text { the sustainability of forest } \\
\text { products and four of them } \\
\text { have begun independent } \\
\text { verification of their } \\
\text { compliance. }\end{array}$ & $\begin{array}{l}\text { It is a standard that } \\
\text { guarantees that its production } \\
\text { processes are responsible for } \\
\text { the environment, including } \\
\text { evaluation and control criteria } \\
\text { in the supply chain. They } \\
\text { work under this principle to } \\
\text { achieve efficient consumption } \\
\text { of the resources used from the } \\
\text { origin of the raw material to } \\
\text { its placing on the market. }\end{array}$ \\
\hline
\end{tabular}

${ }^{1}$ Refibra ${ }^{\text {TM}}$ : Textiles recycling technology; ${ }^{2}$ TENCEL ${ }^{\circledR}$ : A type of fabric. Source: Own authors.

\section{Discussion}

The circular economy is a new paradigm of production and consumption that is characterized by its open system, that is, one that includes the entire value chain of production, and as participants all, [65] from political leaders, business leaders, among others, including consumers, as well as the interrelation and participation of society in general, including family businesses [66], which are an important economic force in the United States and the world [67]. This is a paradigm that has increased the attention of politicians, the world of industry, and academia [68], focusing on efforts to create an increasingly sustainable society [69].

Sustainability in fashion [70] has become a topic on the media agenda for proposals, projects, initiatives, commitments, innovations that seek sustainable growth, focusing on progress towards a circular model, to have countries more sustainable, which has made the subject become more flourishing every day [69].

With what is seen in this article, there is currently great interest in sustainability, and many are betting on moving towards a circular fashion, carrying out proposals, projects, initiatives, commitments, innovations that consider the entire value chain, ranging from eco-efficient and sustainable production and use of resources.

Inditex is betting more every day on the circular economy model, developing training and awareness programs in all the countries where they are present, as well as working in all areas of the value chain [71].

As exposed in this article in the numerical data, we can see in all the areas how their indicators have been changing year after year, improving every possible space to have more responsibility with the environment [72]. It is a company that is not only concerned with selling [73]; even after having sold a garment, it has programs to collect clothes to reuse it and not only reach a garbage dump where it causes damage and contamination.

As can be seen in the following graphs, Inditex takes control of everything related that we placed in the article to review its sustainability indicators, including its sales, consumption, materials (water, waste, energy, gases, cartons, cotton, plastics, among others) showing that it is a company committed to the environment and that as time goes by, improvements are being included focusing on the transition towards the circular economy. It is a company where not only its sales are the most important thing, but the entire chain until it reaches the final consumer and not leaving each garment in the sale, but rather has garment collection programs for reuse [74].

Figure 3 shows the degree of improvement of sustainability indicators for the period 2013-2018, and the relationship of each with the sales. 


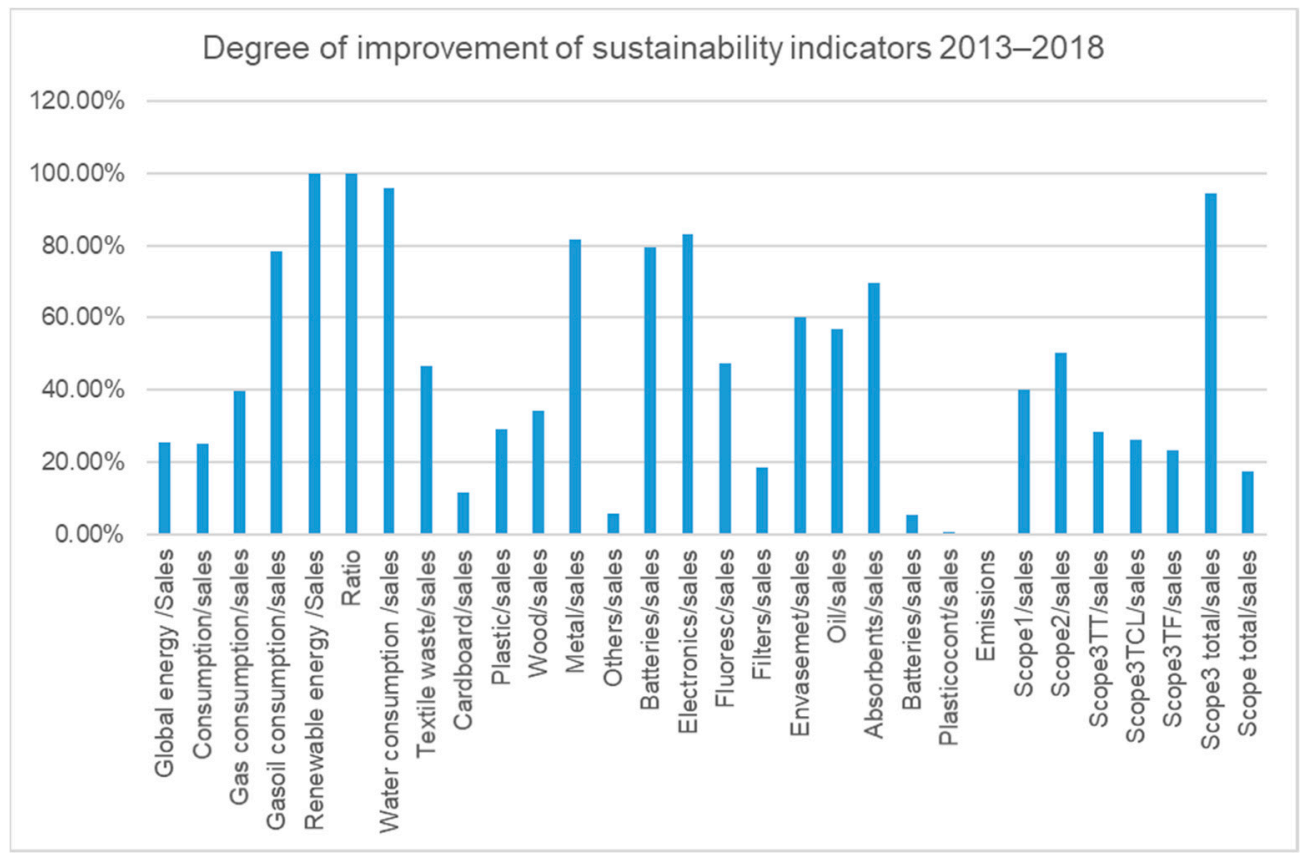

Figure 3. Degree of improvement in Inditex sustainability indicators 2013-2018. Source: Own authors.

Figure 4 shows the degree of improvement of sustainability indicators for the period 2016-2018, and the relationship of each with the sales.

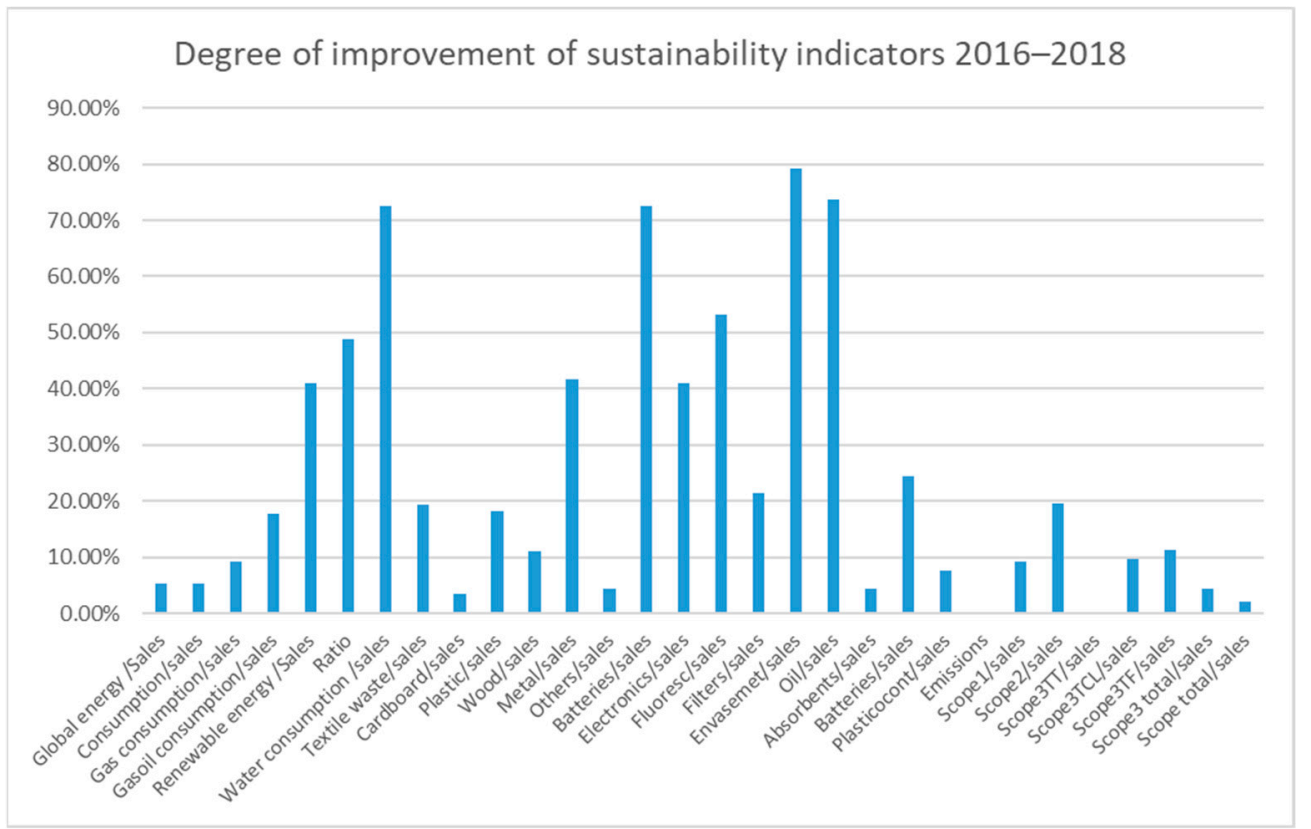

Figure 4. Degree of improvement in Inditex sustainability indicators 2016-2018. Source: Own Authors.

According to the research conducted and the literature review consulted, it was possible to identify lines of research related to the circular economy:

- Circular economy and social development in indigenous communities.

- Circular economy and wellbeing and integral health

- Circular economy and technological development

- Circular economy in water, forest, and soil management.

- Circular economy and residential recycling 


\section{Conclusions}

RQ1: What factors inherent to the Family help the implementation of the CE model?

In the special case of Inditex, throughout the research for this article, we see and verify that Inditex is a company passionate about fashion, motivated to satisfy the needs of its customers and without neglecting; they seek that the effects that they generate are positive for the environment and all stakeholders. Every time, they are looking for environmental strategies that cover the entire value chain from materials, buildings, garments, packaging, clothing collection programs so that it is not only discarded, among others, to become more sustainable every day. Understanding the production value chain is fundamental for the development of a circular economy model, where participants such as consumers, suppliers, intermediaries, politicians, entrepreneurs, and society, in general, interrelate in the management of these models.

RQ2: How is the transition from the linear economy to the CE being put into practice at Inditex?

Sustainability and a healthy economy are moving towards a circular fashion, with proposals, projects, initiatives, commitments, innovations with eco-efficient and sustainable use of resources.

This company responds to the demands of its customers, employees, and shareholders, contributing through the contributions and support it provides to the community in general. Inditex does not only think about selling but has the vision of getting its people to generate value beyond profit, and that is why all affected parties are included as shown in the proposed model.

The areas and their indicators are constantly changing through a process of continuous improvement where they must be monitored promptly to improve every possible space to become more environmentally responsible.

RQ3: In what dimensions related to $\mathrm{CE}$ is Inditex driving the transition towards this model with more force?

Clothing and textiles are an important sector in the world economy and a fundamental part of everyday life [40]. Every day, they are taking more position in the world market, so the company is incorporating improvements that allow it to be innovative, including and taking the sustainable part into account.

The control of its sustainability indicators, including its sales, consumption, materials (water, waste, energy, gases, cartons, cotton, plastics, among others) is fundamental for a company committed to the environment and improvements focusing on the transition to the circular economy.

With the model we propose, the change in the economy involves everyone: companies, governments, and individuals (families), our jobs, our cities, and our products. If pollution and waste are taken care of, keeping products and materials in use, and regenerating natural systems, we can reinvent everything, arriving at a new business model for family businesses.

Author Contributions: Conceptualization, K.N.E., V.M.-M., P.N.-C. and B.S.-S.; methodology, K.N.E., V.M.-M. and P.N.-C.; formal analysis, K.N.E., V.M.-M. and P.N.-C.; investigation, K.N.E., V.M.-M., P.N.-C. and B.S.-S.; resources, K.N.E., V.M.-M., P.N.-C. and B.S.-S.; data curation, K.N.E., V.M.-M., P.N.-C. and B.S.-S.; writing-original draft preparation, K.N.E., V.M.-M. and P.N.-C.; writing-review and editing, K.N.E., V.M.-M., P.N.-C. and B.S.-S.; visualization, K.N.E.; supervision, V.M.-M. and P.N.-C. All authors have read and agreed to the published version of the manuscript.

Funding: This research received no external funding.

Institutional Review Board Statement: Not applicable.

Informed Consent Statement: Not applicable.

Conflicts of Interest: The authors declare no conflict of interest. 


\section{References}

1. European Advisory Council for the Academic Sciences (EASAC). Indicators for a Circular Economy; European Advisory Council for the Academic Sciences: Halle, Germany, 2016.

2. Turker, D.; Altuntas, C. Sustainable supply chain management in the fast fashion industry: An analysis of corporate reports. Eur. Manag. J. 2014, 32, 837-849. [CrossRef]

3. Núñez-Cacho, P.; Molina-Moreno, V.; Corpas-Iglesias, F.A.; Cortés-García, F.J. Family businesses transitioning to a circular economy model: The case of "Mercadona". Sustainability 2018, 10, 538. [CrossRef]

4. Ecopreneur.eu. Circular Economy Update: Overview of Circular Economy in Europe. Available online: https://ecopreneur.eu/ wp-content/uploads/2019/05/Ecopreneur-Circular-Economy-Update-report-2019.pdf (accessed on 1 January 2021).

5. Kirchherr, J.; Reike, D.; Hekkert, M. Conceptualizing the circular economy: An analysis of 114 definitions. Resour. Conserv. Recycl. 2017, 127, 221-232. [CrossRef]

6. UN. Ensure Sustainable Consumption and Production Patterns. Available online: www.un.org/sustainabledevelopment/es/ sustainable-consumption-production/ (accessed on 27 May 2020).

7. Brydges, T. Closing the loop on take, make, waste: Investigating circular economy practices in the Swedish fashion industry. J. Clean. Prod. 2021, 293, 126245. [CrossRef]

8. Caniato, F.; Caridi, M.; Crippa, L.; Moretto, A. Environmental sustainability in fashion supply chains: An exploratory case based research. Int. J. Prod. Econ. 2012, 135, 659-670. [CrossRef]

9. Geissdoerfer, M.; Savaget, P.; Bocken, N.M.P.; Hultink, E.J. The Circular Economy-A new sustainability paradigm? J. Clean. Prod. 2017, 143, 757-768. [CrossRef]

10. Lawrenz, S.; Nippraschk, M.; Wallat, P.; Rausch, A.; Goldmann, D.; Lohrengel, A. Is it all about Information? The Role of the Information Gap between Stakeholders in the Context of the Circular Economy. Procedia CIRP 2021, 98, 364-369. [CrossRef]

11. Ormazabal, M.; Prieto-Sandoval, V.; Puga-Leal, R.; Jaca, C. Circular economy in Spanish SMEs: Challenges and opportunities. J. Clean. Prod. 2018, 185, 157-167. [CrossRef]

12. Samaniego Céspedes, Y.M. Una Apuesta Responsable por la Economía Circular en el Sector de la Moda. El Caso de INDITEX. Bachelor's Thesis, Universidad de Valladolid, Valladolid, Spain, 2019.

13. Ellen MacArthur Foundation. What is The Circular Economy? Available online: www.ellenmacarthurfoundation.org/circulareconomy/what-is-the-circular-economy (accessed on 21 April 2021).

14. Martínez, A.N.; Porcelli, A.M. Estudio sobre la economía circular como una alternativa sustentable frente al ocaso de la economía tradicional (primera parte). Lex Rev. Fac. Derecho Cienc. Política Univ. Alas Peru. 2018, 16, 301-334. [CrossRef]

15. Troschinetz, A.M.; Mihelcic, J.R. Sustainable recycling of municipal solid waste in developing countries. Waste Manag. 2009, 29, 915-923. [CrossRef] [PubMed]

16. Ma, S.; Wen, Z.; Chen, J.; Wen, Z. Mode of circular economy in China's iron and steel industry: A case study in Wu'an city. J. Clean. Prod. 2014, 64, 505-512. [CrossRef]

17. Zorpas, A.A.; Lassaridi, K.; Voukkali, I.; Loizia, P.; Chroni, C.; Georgiou, A.; Fanou, C. Social measuring in the framework of sustainable waste prevention activities. In Proceedings of the International Phytotechnologies Conference, Heraklion, Greece, 30 September-3 October 2014.

18. Reh, L. Process engineering in circular economy. Particuology 2013, 11, 119-133. [CrossRef]

19. Srivastava, S.K.; Srivastava, R.K. Managing product returns for reverse logistics. Int. J. Phys. Distrib. Logist. Manag. 2006, 36, 524-546. [CrossRef]

20. Flynn, A.; Hacking, N.; Xie, L. Governance of the circular economy: A comparative examination of the use of standards by China and the United Kingdom. Environ. Innov. Soc. Transit. 2019, 33, 282-300. [CrossRef]

21. Lieder, M.; Rashid, A. Towards Circular Economy implementation: A comprehensive review in context of manufacturing industry. J. Clean. Prod. 2016, 115, 36-51. [CrossRef]

22. Muthu, S.S. Circular Economy in Textiles and Apparel: Processing, Manufacturing, and Design; Woodhead Publishing: Duxford, UK, 2018; pp. 169-181. ISBN 0081026536.

23. Rossi, E.; Bertassini, A.C.; dos Santos Ferreira, C.; do Amaral, W.A.N.; Ometto, A.R. Circular economy indicators for organizations considering sustainability and business models: Plastic, textile and electro-electronic cases. J. Clean. Prod. 2020, $247,119137$. [CrossRef]

24. Le Breton-Miller, I.; Miller, D. Family firms and practices of sustainability: A contingency view. J. Fam. Bus. Strateg. 2016, 7, 26-33. [CrossRef]

25. Dong, S.; Wang, Z.; Li, Y.; Li, F.; Li, Z.; Chen, F.; Cheng, H. Assessment of comprehensive effects and optimization of a circular economy system of coal power and cement in Kongtong District, Pingliang City, Gansu Province, China. Sustainability 2017,9 , 787. [CrossRef]

26. Berrone, P.; Cruz, C.; Gomez-Mejia, L.R.; Larraza-Kintana, M. Socioemotional wealth and corporate responses to institutional pressures: Do family-controlled firms pollute less? Adm. Sci. Q. 2010, 55, 82-113. [CrossRef]

27. Németh, K.; Németh, S. The Relationship between the Socioemotional Wealth and the Family Businesses' Sustainability. In Proceedings of the International Conference on Technology, Innovation and Industrial Management, Naples, Italy, 16-18 May 2018; pp. 515-523. 
28. Utrilla, P.N.-C.; Torraleja, F.A.G.; Nunez-Cacho Utrilla, P.; Grande Torraleja, F. The importance of mentoring and coaching for family businesses. J. Manag. Organ. 2013, 19, 386-404. [CrossRef]

29. Kalm, M.; Gomez-Mejia, L.R. Socioemotional wealth preservation in family firms. Rev. Adm. 2016, 51, 409-411. [CrossRef]

30. Pineda, A. Valores, el Peso Fuerte de las Empresas Familiares. Available online: https://elempresario.mx/actualidad/valorespeso-fuerte-empresas-familiares (accessed on 15 August 2019).

31. Vallejo, M.C. Is the Culture of Family Firms Really Different? A Value-based Model for Its Survival through Generations. J. Bus. Ethics 2008, 81, 261-279. [CrossRef]

32. Gomez-Mejia, L.R.; Cruz, C.; Berrone, P.; De Castro, J. The Bind That Ties: Socioemotional Wealth Preservation in Family Firms. Acad. Manag. Ann. 2011, 5, 653-707. [CrossRef]

33. Debicki, B.J.; Kellermanns, F.W.; Chrisman, J.J.; Pearson, A.W.; Spencer, B.A. Development of a socioemotional wealth importance (SEWi) scale for family firm research. J. Fam. Bus. Strateg. 2016, 7, 47-57. [CrossRef]

34. Zellweger, T.M.; Nason, R.S.; Nordqvist, M.; Brush, C.G. Why do family firms strive for nonfinancial goals? An organizational identity perspective. Entrep. Theory Pract. 2013, 37, 229-248. [CrossRef]

35. Cruz, C.; Larraza-Kintana, M.; Garcés-Galdeano, L.; Berrone, P. Are family firms really more socially responsible? Entrep. Theory Pract. 2014, 38, 1295-1316. [CrossRef]

36. Eddleston, K.A.; Kellermanns, F.W. Destructive and productive family relationships: A stewardship theory perspective. J. Bus. Ventur. 2007, 22, 545-565. [CrossRef]

37. Schulze, W.S.; Lubatkin, M.H.; Dino, R.N.; Buchholtz, A.K. Agency relationships in family firms: Theory and evidence. Organ. Sci. 2001, 12, 99-116. [CrossRef]

38. Marques, A.D.; Moreira, B.; Cunha, J.; Moreira, S. From waste to fashion-a fashion upcycling contest. Procedia CIRP 2019, 84 , 1063-1068. [CrossRef]

39. Eco-Circular. 3a Edición del Global Change Award. Available online: https:/ / eco-circular.com/2017/09/25/3a-edicion-delglobal-change-award/ (accessed on 6 August 2021).

40. Ministry of the Environment: What the Circular Economy Is. Available online: https:/ / environment.govt.nz/what-governmentis-doing/areas-of-work/waste/ohanga-amiomio-circular-economy/ (accessed on 27 August 2021).

41. Holton, E.F.; Lowe, J.S. Toward a general research process for using Dubin's theory building model. Hum. Resour. Dev. Rev. 2007, 6, 297-320. [CrossRef]

42. Dubin, R. Theory Building, Revised; Free Press/Macmillan: New York, NY, USA, 1978.

43. Olson, P.D.; Zuiker, V.S.; Danes, S.M.; Stafford, K.; Heck, R.K.Z.; Duncan, K.A. The impact of the family and the business on family business sustainability. J. Bus. Ventur. 2003, 18, 639-666. [CrossRef]

44. Stafford, K.; Duncan, K.A.; Dane, S.; Winter, M. A research model of sustainable family businesses. Fam. Bus. Rev. 1999, 12, 197-208. [CrossRef]

45. Danes, S.M.; Stafford, K.; Haynes, G.; Amarapurkar, S.S. Family capital of family firms: Bridging human, social, and financial capital. Fam. Bus. Rev. 2009, 22, 199-215. [CrossRef]

46. Minkler, M. Community Organizing and Community Building for Health, 2nd ed.; Rutgers University Press: New Brunswick, NJ, USA, 2005; ISBN 0813534747.

47. Cennamo, C.; Berrone, P.; Cruz, C.; Gomez-Mejia, L.R. Socioemotional wealth and proactive stakeholder engagement: Why family-controlled firms care more about their stakeholders. Entrep. Theory Pract. 2012, 36, 1153-1173. [CrossRef]

48. Kulig, J.C. Community resiliency: The potential for community health nursing theory development. Public Health Nurs. 2000, 17, 374-385. [CrossRef]

49. Castany, C. Inditex, Una Historia de Éxito Que Cambió el Mundo de la Moda. Available online: www.vanitatis.elconfidencial com/estilo/moda/2018-10-26/inditex-historia_1633098/ (accessed on 6 August 2021).

50. Esbeih, K.N. Relationship: Community-Business-Families. From VOS Viewer Program. 2018. Available online: https://www. vosviewer.com/ (accessed on 30 August 2019).

51. Adde, R.; Fernández, M.; Llanos, I.; Cirilo, M. Caso Estrategia Empresarial: Inditex Breve Historia. Available online: https: / / modarapida.wordpress.com/home/breve-historia/ (accessed on 23 July 2021).

52. Lowe, J.S.; Holton III, E.F. A theory of effective computer-based instruction for adults. Hum. Resour. Dev. Rev. 2005, 4, 159-188. [CrossRef]

53. Lynham, S.A. Quantitative research and theory building: Dubin's method. Adv. Dev. Hum. Resour. 2002, 4, 242-276. [CrossRef]

54. Freeman, R.E. Strategic Management: A Stakeholder Approach; Cambridge University Press: Cambridge, UK, $2010 ;$ ISBN 0521151740.

55. Poplawska, J.; Labib, A.; Reed, D.M.; Ishizaka, A. Stakeholder profile definition and salience measurement with fuzzy logic and visual analytics applied to corporate social responsibility case study. J. Clean. Prod. 2015, 105, 103-115. [CrossRef]

56. Schembri, J.; Tang, Y.K.; Fletcher, M.; Dimitratos, P. How do European trade promotion organisations manage their stakeholders? Int. Bus. Rev. 2019, 28, 101595. [CrossRef]

57. Clarkson, M.B.E. A stakeholder framework for analysing and evaluating corporate social performance. Acad. Manag. Rev. 1995, 20, 92-117. [CrossRef]

58. Phillips, R. Stakeholder Theory and Organizational Ethics; Berrett-Koehler Publishers: San Francisco, CA, USA, 2003 ; ISBN 1609943945.

59. Campopiano, G.; De Massis, A. Corporate social responsibility reporting: A content analysis in family and non-family firms. J. Bus. Ethics 2015, 129, 511-534. [CrossRef] 
60. Fragoso, J.L.P. La creación de la teoría sustentada. Unpublished work. 2000; pp. 1-11.

61. Barr, P.S.; Stimpert, J.L.; Huff, A.S. Cognitive change, strategic action, and organizational renewal. Strateg. Manag. J. 1992, 13, 15-36. [CrossRef]

62. Esrock, S.L.; Leichty, G.B. Social responsibility and corporate web pages: Self-presentation or agenda-setting? Public Relat. Rev. 1998, 24, 305-319. [CrossRef]

63. Maignan, I.; Ralston, D.A. Corporate social responsibility in Europe and the US: Insights from businesses' self-presentations. J. Int. Bus. Stud. 2002, 33, 497-514. [CrossRef]

64. INDITEX. 2020 Annual Report Remuneration of Directors of Industria de Diseño Textil, S.A. Available online: www.inditex.com/ documents /10279/668193/17.+INDITEX+IAR+2020_EN.pdf/5e21f1f4-2e5a-714b-683f-224fa22d7716 (accessed on 23 July 2021).

65. Bocken, N.M.P.; De Pauw, I.; Bakker, C.; Van Der Grinten, B. Product design and business model strategies for a circular economy. J. Ind. Prod. Eng. 2016, 33, 308-320. [CrossRef]

66. Miller, D.; Breton-Miller, I.L. Family Governance and Firm Performance: Agency, Stewardship, and Capabilities. Fam. Bus. Rev. 2006, 19, 73-87. [CrossRef]

67. Gómez-Mejía, L.R.; Haynes, K.T.; Núñez-Nickel, M.; Jacobson, K.J.L.; Moyano-Fuentes, J. Socioemotional wealth and business risks in family-controlled firms: Evidence from Spanish olive oil mills. Adm. Sci. Q. 2007, 52, 106-137. [CrossRef]

68. Martínez-Jurado, P.J.; Moyano-Fuentes, J. Lean management, supply chain management and sustainability: A literature review. J. Clean. Prod. 2014, 85, 134-150. [CrossRef]

69. Singhal, D.; Tripathy, S.; Jena, S.K. Remanufacturing for the circular economy: Study and evaluation of critical factors. Resour. Conserv. Recycl. 2020, 156, 104681. [CrossRef]

70. Pinheiro, E.; de Francisco, A.C.; Piekarski, C.M.; de Souza, J.T. How to identify opportunities for improvement in the use of reverse logistics in clothing industries? A case study in a Brazilian cluster. J. Clean. Prod. 2019, 210, 612-619. [CrossRef]

71. INDITEX. El Nuevo Edificio de Zara.com Reúne Sostenibilidad y Tecnología. Available online: www.inditex.com/es/article? articleId=662398\&title=El+nuevo+edificio+de+Zara.com+reúne+sostenibilidad+y+tecnología (accessed on 25 March 2021).

72. INDITEX. Right to Wear. Available online: www.inditex.com/un-modelo-sostenible/right-to-wear (accessed on 20 March 2021).

73. INDITEX. El Presidente de Inditex, Pablo Isla, Firma Con 31 Empresas Globales de Moda Un Compromiso Total Por la Sostenibilidad. Available online: $w w w$.inditex.com/es/article? articleId=635111\&title=El+presidente+de+Inditex $\% 2 \mathrm{C}+$ Pablo+Isla $\% 2 \mathrm{C}+$ firma + con + 31+empresas+globales+de+moda+un+compromiso+total+por+la+sostenibilidad (accessed on 8 October 2020).

74. INDITEX. Our Commitment to the Environment. Available online: www.inditex.com/en/our-commitment-to-the-environment (accessed on 20 March 2021). 